J. Lake Sci. (湖泊科学), $2006, \mathbf{1 8}(4): 377-386$

http:// www. jlakes. org. E-mail: jlakes@ niglas. ac.cn

(c) 2006 by Journal of Lake Sciences

\title{
不同尺度流域地表径流氮、磷浓度比较”
}

\author{
李恒鹏 ${ }^{1}$, 杨桂山 ${ }^{1}$, 黄文钰 ${ }^{1}$, 于兴修 ${ }^{2}$, 梁 涛 $^{3}$, 李兆富 ${ }^{1}$ \\ (1: 中国科学院南京地理与湖泊研究所,南京 210008) \\ $(2:$ 临沂师范学院地理与旅游学院,临沂 276005) \\ (3: 中国科学院地理科学与资源研究所, 北京 100101)
}

\begin{abstract}
摘 要: 选择太湖上游为研究对象, 采集了 $1-400 \mathrm{~km}^{2}$ 不同尺度小流域产出径流 TN、TP 浓度实测数据,结合前期开展的 地表坡面流人工暴雨实验监测结果, 开展不同尺度流域水质监测对水体面源污染产出浓度估算影响的比较研究, 探讨流 域尺度之间人渗、汇流以及伴随的流域生态系统营养盐调节机制的差异. 结果表明, 流域监测尺度对土地利用面源污染产 出浓度估算有较大影响. 地表坡面流由于未经过流域汇流过程伴随的下渗滤过与吸附等过程,产出径流 TN、TP 浓度一般 高于小流域. 小流域林地生态系统具有较强的人渗机制、接近自然的生态沟谷汇流网络, 对面源污染 TN、TP 有较强的削 减作用. 农业生态系统较弱的人渗机制、人工沟渠汇流网络对面源污染 TN 、 TP 的削减作用较弱. 现代农业造成流域面源 污染增加不仅仅是因为人类农业活动对流域局部土体及养分的改变,农业生态系统改变流域自然生态系统整体水文过程 及营养盐调节机制也是面源污染增加的重要因素之一,恢复小尺度的生态沟谷网络系统对削减流域面源污染具有重要的 意义.
\end{abstract}

关键词: 太湖流域;面源污染;土地利用;坡面流;流域尺度

\section{Comparison of nitrogen and phosphorus concentration of runoff from different spatial scale watersheds}

\author{
LI Hengpeng ${ }^{1}$, YANG Guishan ${ }^{1}$, HUANG Wenyu ${ }^{1}$, YU Xinxiu ${ }^{2}$, LIANG Tao ${ }^{3} \&$ LI Zhaofu ${ }^{1}$ \\ (1: Nanjing Institute of Geography and Limnology Research, CAS, Nanjing 210008, P. R. China) \\ (2: Institute of Geographic Sciences and Natural Resources Research, CAS, Beijing 100101, P. R. China) \\ (3: College of Geography and Tourisim, Linyi Normal University, Linyi 276005, P. R. China )
}

\begin{abstract}
Based on artificial rain experiments and field monitoring to sub-watersheds in different spatial scale ( from 1 to $400 \mathrm{~km}^{2}$ in area) in Taihu upper-river basin, The runoff mean concentration of non-point source nitrogen and phosphorus are assessed according to different spatial scale field monitoring. The discrepancy of watershed nutrient decay function, due to different soil infiltration and runoff routing process in different watershed spatial scale, is analyzed. The results proved that runoff mean concentration of nitrogen and phosphorus in different watershed scale is with more discrepancy. The runoff mean concentration of nitrogen and phosphorus based on overland flow monitoring is higher than that of watershed outlet monitoring, because the overland flow monitoring does not represent the soil infiltration and runoff routing processes relating to nutrient decay. The forest land of watershed, with strong soil infiltration and more natural stream systems, have more nutrient decay function than that of the farm land of watershed with weak soil infiltration and artificial canal systems. It is important factor of increasing non-point source nitrogen and phosphorus to alter watershed hydrological system and ecological system by modern farm activities. Restoration and remediation of natural ecological stream system is helpful to non-point source pollutant abatement of watersheds.
\end{abstract}

* 国家自然科学基金 $(40371111,40401056$ )、“973 计划” (2002CB412310)、中国科学院知识创新项目 (KZCX1 - SW 12) 联合资助. 2005-09-21 收稿;2006-01-25 收修改稿. 李恒鹏, 男, 1973 年出生,博士, 副研究员; E-mail: hpli @ niglas. ac. cn. 
Keywords: Taihu Basin; non-point source pollution; land use; overland flow; watershed spatial scale

从面源污染的源头出发, 分析污染物产生、输移的各个环节和过程, 研究不同用地类型的污染物产出是 合理估算面源污染的有效途径之一. 面源污染的产出一般通过野外实测进行估算, 输出强度采用单位面积 负荷量或用地类型地表径流浓度来表示, 其中浓度指标便于不同年份、不同区域比较分析,被较多的研究者 采用. 目前国外已经开展了大量的流域暴雨事件实测研究, 并设立小流域连续监测站点, 估算暴雨事件平均 浓度 (EMC, Event Mean Concentration) 的区域代表性实测参数. 如 Baird 等 1996 年在美国德克萨斯南部濒海 流域开展了不同用地类型 $\mathrm{EMC}$ 参数的估算工作 ${ }^{[1]}$, 已经较多地应用于面源污染估算模型中 ${ }^{[2-4]}$. 澳大利亚 CSIRO 于 2002 年在墨尔 - 达令流域通过暴雨径流监测获取 EMC 参数, 在此基础上开发 EMSS 模型用到大 流域的面源负荷估算中 ${ }^{[5]}$. 我国针对面源污染开展了一些实测研究, 如梁涛、黄满向等通过人工暴雨实验 开展了地表坡面流的监测工作 ${ }^{[6,7]}$, 夏立忠开展了城镇用地类型地表径流的实测研究 ${ }^{[8]}$; 连纲、王德建等开 展了氮素淋失的田间实验研究 ${ }^{[9]}$, 王少平等开展了野外小区监测工作 ${ }^{[10]}$; 小流域的监测近年开展工作较 多, 流域监测尺度从 0.5-100 $\mathrm{km}^{2}$ 不等 ${ }^{[11-15]}$. 不同监测尺度估算的面源污染产出有较大差异, 大者可达 1 个数量级. 由于不同的监测尺度涉及不同的流域产汇流过程以及伴随的渗滤、吸附等机制, 虽然这些研究因 区域不同缺乏可比性,但我们不能否认这些差异与监测尺度有关. 在流域面源污染负荷估算中,采用不同参 数因径流累积运算导致误差放大, 估算结果差异较大. 目前在尚缺乏对流域污染物产出、输移过程与机理认 识的背景下, 在同一区域, 开展不同次级流域尺度的系统监测以及不同尺度的参数比较研究, 可以揭示出流 域尺度之间发生的汇流过程以及伴随的营养盐调节机制对面源污染产出的影响, 对参数的合理应用以及水 环境管理有着非常重要的意义. 本项研究针对面源污染产出的高度不确定性, 以太湖上游流域为研究区, 系 统地开展了从 1-400 $\mathrm{km}^{2}$ 的小流域实测研究, 结合前期开展的坡面流人工暴雨实验结果, 比较不同尺度的 小流域产出径流面源污染浓度特征,重点探讨监测尺度对流域面源污染产出估算的影响.

\section{1 研究区域及监测方法}

面源污染产出和输移过程与流域产、汇流过程同步,因此面源污染和流域的水文过程以及流域用地类 型等因素密切联系. 为了便于比较分析, 本项研究采用径流平均浓度指标代表不同用地方式的面源污染产 出率. 由于不同空间尺度涉及不同的流域过程, 监测尺度大小涉及的污染物产出、输移过程也有差别 (图 1). 响应单元与坡面流尺度的监测, 主要反映产流过程中地表冲刷产生的面源污染; 小区和沟谷汇流区监 测包括坡面产流、坡面汇流、沟谷汇流、土壤渗漏和壤中流, 面源污染物在输移过程中伴随着冲刷、土壤吸 附、渗漏和滤过等过程; 典型小流域尺度指具有流域产汇流的全过程, 常年具有一定的流量, 流域出口的流
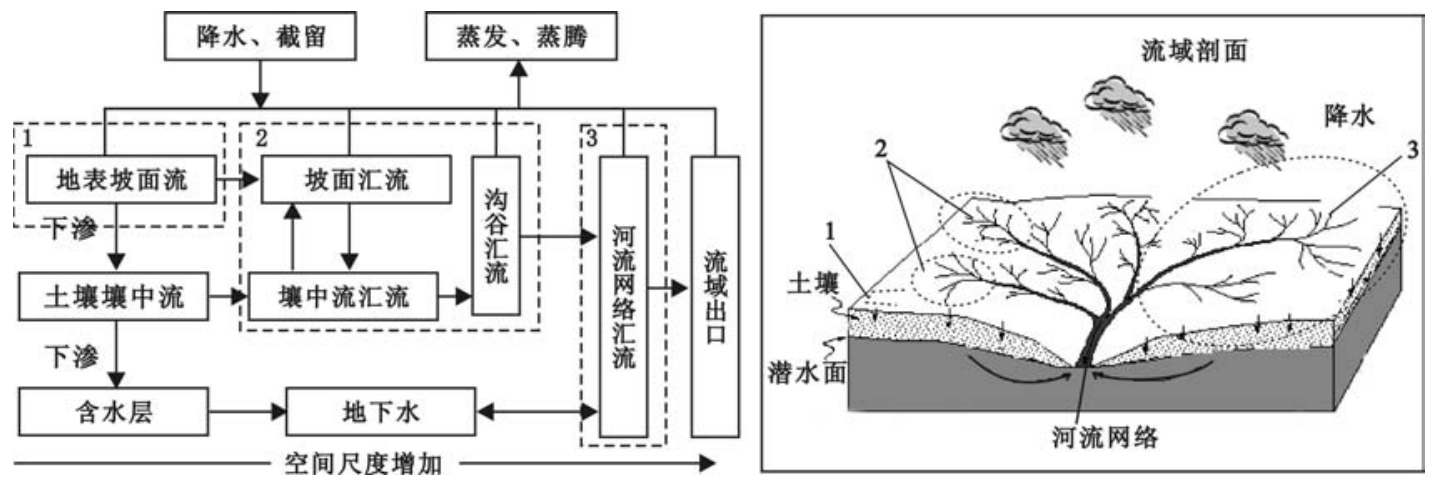

图 1 流域面源污染产出研究监测尺度与过程示意图

（1：响应单元与坡面流尺度; $:$ 小区监测与沟谷汇流区尺度;3: 典型小流域尺度）

Fig. 1 Diagram of the watershed spatial scales and processes 
量曲线具有流域水文过程的基本特征, 典型小流域尺度监测反映流域产汇流的最终产出, 所得参数在污染 物负荷估算中更有代表意义. 由于各个尺度之间没有明确的界限, 本项研究监测工作拟采用人工暴雨实验 代表地表坡面流的面源污染产出浓度特征, 监测 $1 \mathrm{~km}^{2}$ 到 $400 \mathrm{~km}^{2}$ 的汇水区探讨从沟谷汇水区到典型小流域 尺度的面源污染产出浓度特征.

选择太湖上游相对独立的浙西水利分区以及湖西区的湖滏流域为研究区, 位于太湖上游西南地区, 是 太湖上游最大的山区水系, 地貌类型包括山地、丘陵和平原, 地面高程在 $2-1578 \mathrm{~m}$ 之间, 属于亚热带气候, 流域平均年降水量为 $1022-1897 \mathrm{~mm}$, 降雨集中于 4-9 月份, 自北向南逐渐增加. 流域人湖水量占太湖人 湖量的 50\% 左右, 水质以三类水为主. 流域地带性土壤为红壤, 其次为黄壤, 农业土壤主要是水稻土. 用地 类型以林地、耕地为主, 其次为居民地、果园、草地和水体, 其中林地约占 $53.78 \%$, 耕地占 $37.78 \%$. 为分析 面源污染产出特征, 采样点选择水力关系明晰, 污染源以农业面源为主的上游小流域, 在太湖上游的浙西区 设置断面 44 个, 在湖西区的湖滏流域设置监测断面 16 个, 共计 60 个监测断面 (图 2), 流域面积从 $1.59-$ $392 \mathrm{~km}^{2}$ 不等. 监测断面分布如图 2 所示, 分析指标为总氮 (TN) 和总磷 (TP).

不同尺度的监测方法如下:

(1) 地表坡面流的暴雨实验监测: 人工降雨实验 装置由中国科学院地理与资源研究所研制, 主要包括 供水系统、人工模拟降雨机、供收集并测定径流量的 $\mathrm{V}$ 型受水槽等三部分. 实验样方长 $2 \mathrm{~m}$, 宽 $1.5 \mathrm{~m}$, 四周 设置塑料挡板防止降雨泥沙溅出. 用地类型选取主要 根据研究区域植被类型组成特征, 选择竹林、松林和 稻田三种主要类型, 为确保代表性, 各用地类型选择 三个代表性样方进行实验, 采用三个样方的平均数. 由于暴雨是该地区的主要径流特征, 故人工降雨实验 时, 选用的暴雨强度较大, 为 $2.0 \mathrm{~mm} / \mathrm{min}$, 属暴雨类 型. 野外实验地点位于浙西区湖州市杨家埠镇, 于 2001 年 9 月 20-27 日实施, 分别采集各样方的表土 样品, 在实验室分析土壤的 $\mathrm{TN} 、 \mathrm{TP}$, 产流过程及水质

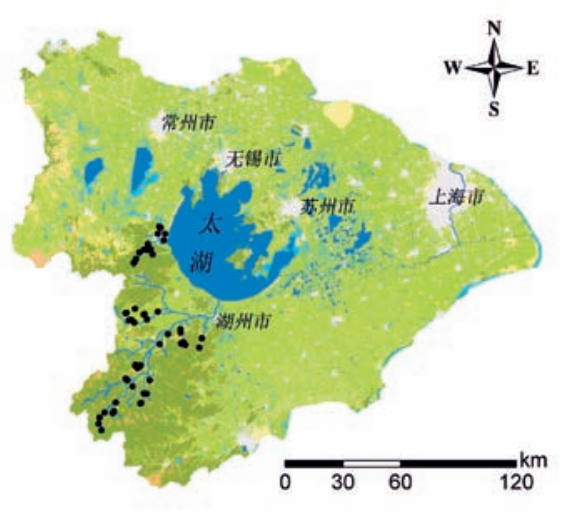

图 2 研究区域与水质监测断面分布 样品采样时间间隔为开始产流后每 4 分钟采样一次. 重点分析暴雨过程流域地表坡面流的面源污染产出变 化特征.

(2) 小流域暴雨连续监测: 选择以农业用地为主的宜兴县湖滏流域, 总面积 $91.37 \mathrm{~km}^{2}$, 林地面积约占 $76.7 \%$, 耕地约占 $19 \%$, 农村居民地面积约占 $2.8 \%$. 水文测量严格按照水文测量规范实施, 2001 年 7 月 20 日安装水尺, 并测量河口断面, 8 月 25 日到 9 月 1 日对两场暴雨进行水量、水质同步测量, 测量水质样品每 天采集 3-4 次, 采样时间为 7:00,12:00 和 17:00, 如出现洪峰则增加采样一次. 重点分析暴雨过程小流域 面源污染输出的时间变化特征.

(3) 不同尺度小流域水质监测: 监测小流域按照以下原则选取. 一是子流域分布于上游地区, 使其成为 相对独立的地理单元, 可以排除外界水源的影响; 二是子流域内无大的城镇分布, 无重要点源排放, 使断面 监测能够反映流域面源污染的特征; 三是子流域空间尺度覆盖 $1-400 \mathrm{~km}^{2}$ 的范围, 便于比较空间尺度对面 源污染产出的影响, 揭示出不同空间尺度之间的汇流过程及生态系统营养盐调节机制对面源污染产出的影 响规律. 根据以上原则设置河流监测断面共计 60 个, 其中浙西区设置断面 44 个, 湖西区湖滏流域设置监 测断面 16 个. 1-400 $\mathrm{km}^{2}$ 的流域水质监测采用代表性暴雨径流采样监测方法, 全年共 3 次采样, 分别在梅 雨期, 台风雨期和枯水期采集, 由于研究区的泄洪过程一般在 2-3 日内结束, 每次采样过程选择降雨后期 或降雨之后 1-2 日内完成. 监测工作分别在 2004 年 5-7 月,2004 年 9 月和 2004 年 $11-12$ 月完成. 重点分 析不同空间尺度流域面源污染产出的代表性参数. 


\section{2 不同尺度流域产出径流氮、磷浓度的时间分布特征}

\section{1 坡面流面源污染浓度的时间分布特征分析}

地表坡面流的面源污染主要来源于降水对坡面的冲刷,受不同用地类型以及土壤理化性质差异影响， 坡面流水文特征及氮磷浓度有所不同. 实测获得三种用地类型各样方的表土氮、磷含量分别为: 竹林土壤 $\mathrm{TN}$ 含量为 $1532 \mathrm{mg} / \mathrm{kg}$, TP 含量为 $1002 \mathrm{mg} / \mathrm{kg}$; 松林土壤 TN 含量为 $1475 \mathrm{mg} / \mathrm{kg}$, TP 含量为 $961 \mathrm{mg} / \mathrm{kg}$; 稻田 土壤 TN 含量为 $1277 \mathrm{mg} / \mathrm{kg}$, TP 含量为 $705 \mathrm{mg} / \mathrm{kg}$. 竹林、松林和稻田的平均坡度分别为 $4.4^{\circ} 、 13.8^{\circ}$ 和 $0^{\circ}$, 图 3 是研究区典型用地类型的人工暴雨实验监测结果. 可以看出, 坡面流的流量特征表现为初期增加较快, 逐渐趋于稳定,趋于稳定所需时间有所不同, 产流后, 松林的流量稳定时间最早, 其次是竹林和稻田, 稳定流 量以稻田为最高, 其次为竹林和松林, 说明土壤下渗能力松林最高, 竹林次之, 稻田最低. 坡面流的 TN 和 TP 浓度因不同用地类型表土氮磷含量差异也不相同, TN 浓度特征表现为竹林最高, 平均为 $7.78 \mathrm{mg} / \mathrm{L}$, 其次为 松林和稻田,分别为 $5.84 \mathrm{mg} / \mathrm{L}$ 和 $3.98 \mathrm{mg} / \mathrm{L}$; TP 浓度特征和 TN 类似, 竹林坡面流 TP 浓度最高, 平均为 $3.32 \mathrm{mg} / \mathrm{L}$, 松林和稻田的比较接近, 分别为 $0.93 \mathrm{mg} / \mathrm{L}$ 和 $0.81 \mathrm{mg} / \mathrm{L}$. 比较不同用地类型地表坡面流 TN、TP 产出与土壤养分及坡度特征可以看出, 导致实验地点竹林和松林高于稻田原因, 一方面是由于竹林试验点 表土 TN 、TP 含量最高、松林次之、稻田最低,另一方面竹林和松林分布于坡度较大的丘陵坡地,稻田分布于 平坦的地段,而同样强度的降雨下,坡面流在坡度较大地段的侵蚀能力高于坡地较小的地段,张乃明等的人 工降雨实验研究也证实坡度对坡面流营养盐输出有较大影响 ${ }^{[26]}$. 坡面流 TN、TP 浓度随时间变化都表现为 产流初期浓度较高, 经历初始快速下降之后、转变为缓慢下降并趋于稳定特征, 快速下降一般在产流后 10 - 14min, 随用地类型差异略有不同, 其中竹林、松林和稻田产流后前 10 分钟的 TN 累积平均浓度分别为 $10.63 \mathrm{mg} / \mathrm{L} 、 9.21 \mathrm{mg} / \mathrm{L}$ 和 $5.22 \mathrm{mg} / \mathrm{L}$, 随后时间的累积平均浓度是 $6.36 \mathrm{mg} / \mathrm{L} 、 4.15 \mathrm{mg} / \mathrm{L}$ 和 $3.36 \mathrm{mg} / \mathrm{L}$, 两者相差分别是 $1.67 、 2.22$ 和 1.55 倍. 竹林、松林和稻田产流后前 10 分钟的 TP 累积平均浓度分别为 4.25 $\mathrm{mg} / \mathrm{L} 、 1.41 \mathrm{mg} / \mathrm{L}$ 和 $1.06 \mathrm{mg} / \mathrm{L}$, 随后时间的累积平均浓度是 $2.86 \mathrm{mg} / \mathrm{L} 、 0.69 \mathrm{mg} / \mathrm{L}$ 和 $0.68 \mathrm{mg} / \mathrm{L}$, 两者 相差分别是 $1.49 、 2.06$ 和 1.55 倍.
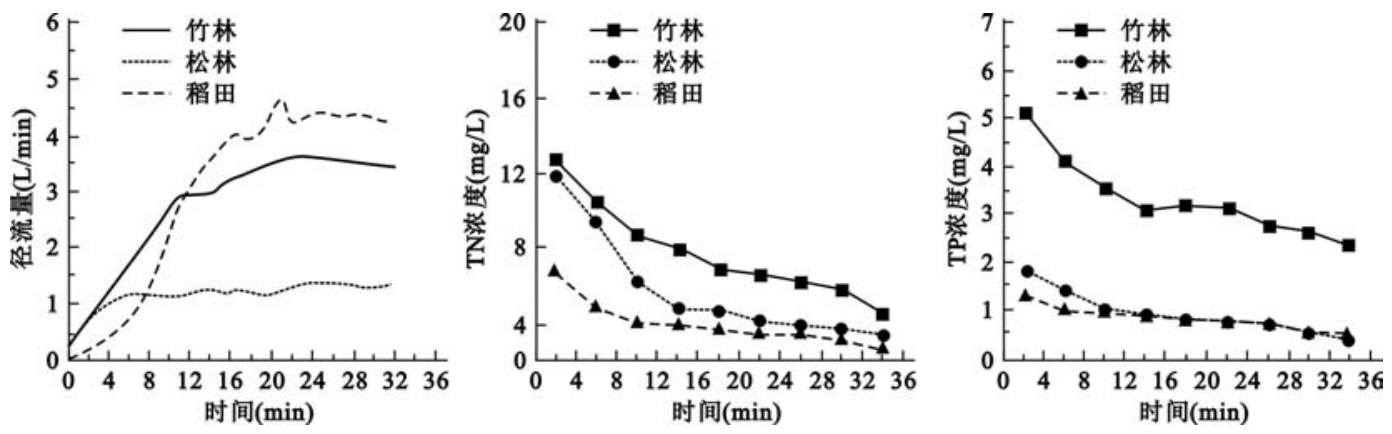

图 3 暴雨径流过程坡面流 TN TP 浓度特征

Fig. 3 The TN and TP concentration of overland flow in rain-runoff process

\section{2 小流域暴雨径流面源污染浓度的时间分布特征}

小流域出口监测与地表坡面流监测不同,不仅反映地表坡面产流过程,还反映壤中流、坡面汇流、沟谷 汇流的影响, 代表产流后经过下渗、汇流以及伴随的土壤渗滤、吸附等营养盐调节过程影响后的最终产出. 图 4 中 I 为太湖上游湖滏小流域连续 $8 \mathrm{~d}$ 的暴雨径流监测结果, 流域以林地为主, 面积约占 $76.7 \%$, 其次为 耕地,约占 $19 \%$,无大的城镇分布,基本上可以代表流域暴雨径流面源污染浓度的时间变化特征, 图中线状 表示流量过程线,对应左边的 $\mathrm{Y}$ 轴,散点表示同步监测的水质指标,对应右边的 Y 轴. 比较流量过程线与同 步水质变化可以看出, 流域出口 TN、TP 的浓度和流量变化趋势完全不同,一般来说, 同一监测断面流量与 流速是一致的, 因此可以得出流域面源污染物浓度和流域流量、流速没有显著联系. 在连续 $8 \mathrm{~d}$ 的暴雨监测 中, $\mathrm{TN}$ 浓度相对稳定, 基本上在一定的数值范围内波动, 没有明显的变化趋势, $\mathrm{TP}$ 浓度呈缓慢下降并逐渐 
趋于稳定的趋势. 两个指标的平均值与标准误差分别为 TN $(3.070 \pm 0.101 \mathrm{mg} / \mathrm{L}) 、 \mathrm{TP}(0.030 \pm 0.004 \mathrm{mg} /$ L), 误差值分别占平均估值的 $3 \%$ 和 $13 \%$. 与地表坡面流面源污染浓度随时间的变化幅度进行比较发现, 小 流域出口面源污染在整个降水径流过程中变化较小,揭示出小流域地表径流在下渗、坡面汇流、沟谷汇流以 及河网汇流过程中,受土壤渗滤、吸附等营养盐调节机制影响径流面源污染浓度趋于稳定.

由于水文、水质同步监测的野外工作量较大,本项研究只获得一个典型流域暴雨过程水量水质同步监 测数据, 为了使分析结果更具有代表性,笔者将湖滏流域监测结果与黄云凤在福建东南沿海九龙江的两个 小流域暴雨连续监测结果进行比较分析 ${ }^{[13]}$, 图 4 中 II 为九龙江流域选择的两个汇水区, 分别为下庄汇水区 和雁石汇水区,下庄汇水区以坡地果园用地类型为主, 雁石汇水区为以水稻田为主, 面积分别为 $5.68 \mathrm{~km}^{2}$ 和 $3.51 \mathrm{~km}^{2}$. 图中流量过程线与同步水质变化比较可以看出,这两个小流域的时间变化过程与湖滏流域类似, $\mathrm{TN}$ 和 TP 浓度与流速、流量没有显著的联系. 从整个暴雨过程的 TN、TP 浓度变化趋势来看,两个小流域 $\mathrm{TN}$ 和 TP 都表现出降雨初期略高的特征, 幅度远小于坡面流的变化; 浓度在整个降水径流过程中基本上在一定 范围内波动, 无明显变化趋势.
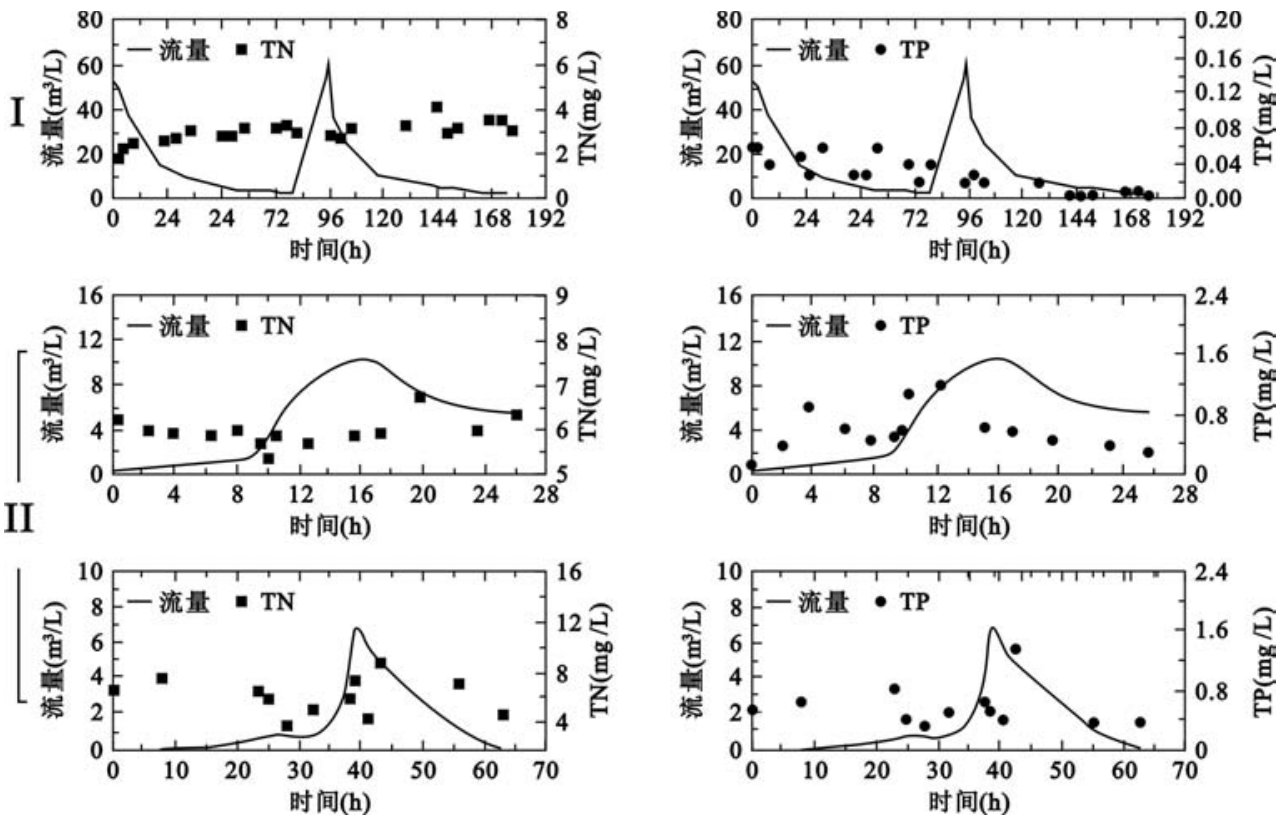

图 4 典型流域暴雨径流过程及 $\mathrm{TN} 、 \mathrm{TP}$ 浓度变化特征

( I : 湖滏流域; II : 九龙江两个小流域)

Fig. 4 Rain-runoff process of typical watershed and variation feature of TN \&TP concentration

\section{3 不同尺度流域径流面源污染氮、磷浓度比较分析}

\section{1 流域空间尺度与面源污染浓度关系}

小流域暴雨连续监测证实流域面源污染 TN、TP 浓度和流域流速、流量没有直接联系, 而且整个降雨过 程中浓度相对稳定, 因此可以认为流域泄洪时段内单次监测结果基本上能够代表流域暴雨过程面源污染产 出特征. 为获取各监测断面控制流域的基本地理信息,采用 1:50000 地形图数字化建立流域数字地形 (DEM) 和河流分布图层, 利用 Arcgis 的水文分析模块 Archydro 进行子流域划分, 获取以 60 个监测断面为 出口的小流域分布,并统计各子流域的面积; 流域土地利用信息采用 TM 卫星影像的目视解译结果, 并将原 分类系统合并归类为林地、耕地、建筑用地和水体四大类,在 ArcGIS 软件环境下将小流域边界与土地利用 分布进行叠加分析, 统计各小流域的用地类型组成结构,建立各小流域的面积、不同用地类型所占比例信 息,结合流域出口实测 TN TP 的浓度, 比较流域尺度、流域用地组成与面源污染浓度的关系. 为便于比较分 
析, 将小流域按照用地类型组成结构划分为林地面积占 $90 \%$ 以上、林地面积占 $85 \%$ 以上、耕地面积占 $30 \%$ 以上三个子集, 分别绘制流域面积与出口 TN、TP 实测浓度关系散点图 (图 5). 由图看出, 三个流域子集因 流域面积不同其出口 TN、TP 浓度均有较大变化, 其中前两个以林地为主的流域子集 TN、TP 的变化幅度分 别为 $0.572-2.411 \mathrm{mg} / \mathrm{L}$ 和 $0.009-0.082 \mathrm{mg} / \mathrm{L}$, 耕地占 $30 \%$ 以上的流域子集 $\mathrm{TN} 、 \mathrm{TP}$ 的变化幅度分别为 1 . $102-2.621 \mathrm{mg} / \mathrm{L}$ 和 $0.031-0.166 \mathrm{mg} / \mathrm{L}$. 三个流域子集中, 前两个子集流域以林地为主, 受人类活动影响 较少, 而且子集内各流域用地结构差异较小, 能够较好地揭示流域尺度对面源污染浓度影响的规律. 变化趋 势表现为: $1-20 \mathrm{~km}^{2}$ 尺度范围内, 面源污染 $\mathrm{TN}$ 、TP 浓度随空间尺度增加呈逐渐减少的趋势, $20 \mathrm{~km}^{2}$ 以上流 域 TN、TP 浓度变化较小, 而且随尺度增大趋于稳定, $50 \mathrm{~km}^{2}$ 以上流域流域面源污染浓度基本趋于稳定. 这 一变化趋势说明面源污染在流域产、汇流过程中, 受吸附和滤过等流域生态系统营养盐调节功能的影响, 浓 度逐渐降低, 尤其是小尺度流域中沟谷汇流对流域面源污染有较大的削减作用. 第三个小流域子集中因用 地类型组成较为复杂, 变化趋势不显著.
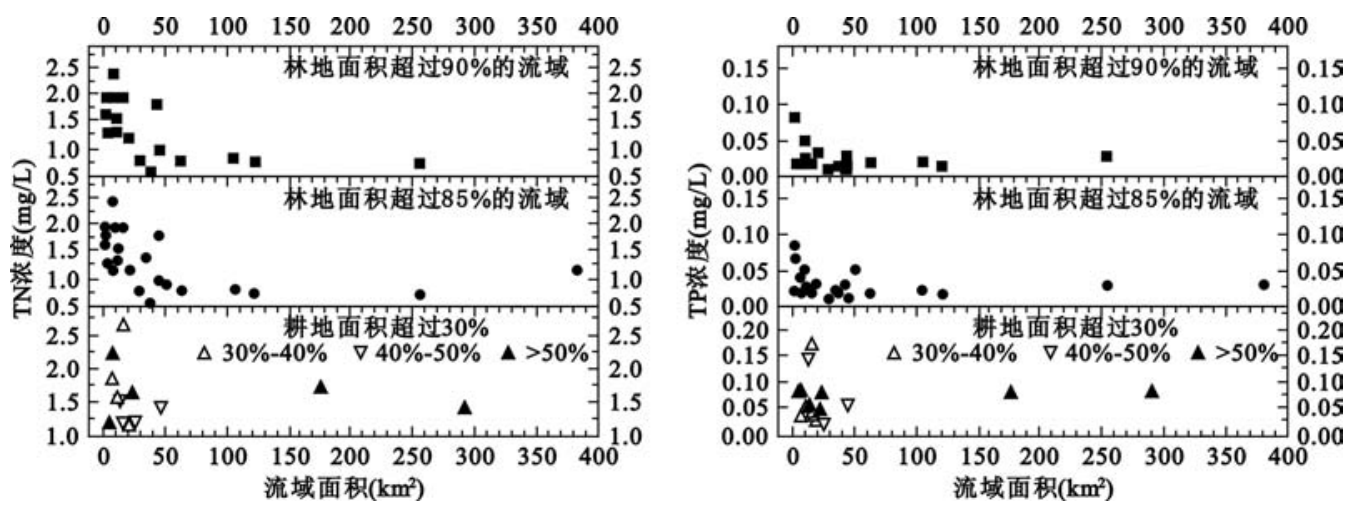

图 5 流域空间尺度与出口径流 TN 、TP 浓度关系

Fig. 5 The relationship between watershed spatial scale and TN \& TP concentration of runoff

为了进一步定量化分析小流域面源污染浓度随空间尺度的变化趋势,将三个流域子集分别按照 $1-20$ $\mathrm{km}^{2} 、 20-50 \mathrm{~km}^{2}$ 和 $50 \mathrm{~km}^{2}$ 三个典型尺度进行统计, 采用平均值表示典型尺度的污染物浓度特征、标准差代 表典型尺度范围内参数的稳定性, 如图 6 所示, 图中三个分区代表三个典型尺度范围, 散点代表相应尺度范 围内污染物平均值, 以散点为中心的垂直误差线代表标准差. 图中显示, 以林地为主的两个子集都表现出 1 $-20 \mathrm{~km}^{2}$ 尺度流域面源污染 TN、TP 浓度最高的特征, 到 $20-50 \mathrm{~km}^{2}$ 尺度范围内浓度显著降低, 证实 $1-20$ $\mathrm{km}^{2}$ 小尺度流域的沟谷汇流过程对面源污染 TN、TP 有较强的削减作用; $20-50 \mathrm{~km}^{2}$ 和大于 $50 \mathrm{~km}^{2}$ 两个典型 尺度的面源污染浓度比较接近, 其中 $20-50 \mathrm{~km}^{2}$ 的 TN 产出浓度略高, 说明这一尺度范围河道汇流削减作 用减弱, TP 的结果略有不同, 大于 $50 \mathrm{~km}^{2}$ 的流域 TP 产出浓度略高, 主要是因为林地流域 TP 产出较低, 对人 类活动影响较为敏感,而随流域尺度的增大,所选流域或多或少地受人类活动的影响. 比较三个典型尺度的 参数稳定性发现, 基本上表现为 $1-20 \mathrm{~km}^{2}$ 尺度的标准差最大, 产出浓度具有很大的不确定性; $20-50 \mathrm{~km}^{2}$ 尺度的流域标准差明显减小, 说明产出浓度不稳定性减弱,但仍有较大的不确定性; $50 \mathrm{~km}^{2}$ 以上尺度的流域 标准差非常小, 说明该尺度范围内不同监测断面监测值差异最小, 产出浓度不确定性较小. 这一规律表现最 突出的是林地占 $90 \%$ 以上的流域子集, 主要因为流域子集内各小流域用地类型组成结构最为一致,而且受 人类活动影响最少. $50 \mathrm{~km}^{2}$ 以上流域面源污染产出浓度指标最为稳定主要是因为该尺度流域常年具有稳定 的流量,包括了流域产汇流的全过程,流量出口的流量曲线具有流域水文过程的基本特征,基本上代表了流 域完整水文过程的最终产出特征,因此该尺度流域监测参数在较大的流域应用中具有很好的应用价值.

\section{2 小流域不同尺度主要用地类型面源污染浓度估算}

为比较流域不同用地类型面源污染浓度估算结果与监测尺度的关系,揭示接近自然的林地生态系统与 

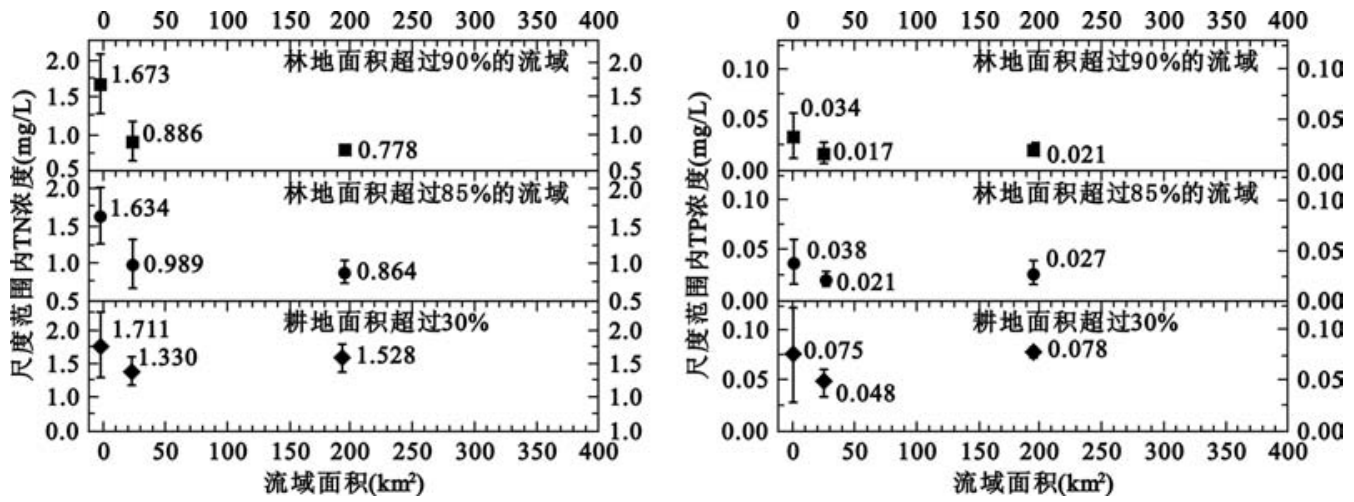

图 6 不同尺度流域出口 TN/TP 浓度变化趋势与稳定性分析

Fig. 6 The trend and stability analyses of TN \& TP concentration of watershed outlet in different spatial scale

人工农业生态系统对营养盐调节机制的差异,需要计算不同尺度单一用地类型的面源污染浓度. 本项研究 首先根据各流域的林地所占比例进行排序,获取林地为主的流域共 15 个,所选流域子集内林地面积总体平 均为 $95 \%$, 子集内各流域的林地面积都超过 $90 \%$, 无集中居民点, 基本上能够代表林地流域的面源污染 $\mathrm{TN} 、 \mathrm{TP}$ 产出. 将子集内流域按照不同空间尺度进行统计分析, 获取三个典型小流域尺度的产出径流 TN、TP 浓度, 如表 1 所示, $1-20 \mathrm{~km}^{2}$ 以上流域, 林地面源污染产出径流的 TN、TP 浓度分别为 $1.673 \pm 0.374 \mathrm{mg} / \mathrm{L}$ 和 $0.034 \pm 0.018 \mathrm{mg} / \mathrm{L} ; 20-50 \mathrm{~km}^{2}$ 尺度范围内流域林地产出径流的 TN、TP 浓度分别为 $0.886 \pm 0.424 \mathrm{mg} / \mathrm{L}$ 和 $0.017 \pm 0.015 \mathrm{mg} / \mathrm{L}$; 大于 $50 \mathrm{~km}^{2}$ 尺度范围内流域林地产出径流 $\mathrm{TN} 、 \mathrm{TP}$ 浓度分别为 $0.778 \pm 0.056 \mathrm{mg} / \mathrm{L}$ 和 $0.021 \pm 0.009 \mathrm{mg} / \mathrm{L}$.

表 1 不同尺度流域林地产出径流的 TN、TP 浓度统计特征

Tab. 1 The statistical feature of runoff concentration of TN \& TP from forest land in different spatial scale watershed

\begin{tabular}{cccccccc}
\hline \multirow{2}{*}{ 流域面积 } & \multicolumn{3}{c}{$\mathrm{TN}(\mathrm{mg} / \mathrm{L})$} & & \multicolumn{3}{c}{$\mathrm{TP}(\mathrm{mg} / \mathrm{L})$} \\
\cline { 7 - 8 } \cline { 7 - 8 } & 均值 & 标准差 & $95 \%$ 置信范围 & 均值 & & 标准差 & $95 \%$ 置信范围 \\
\hline $1-20 \mathrm{~km}^{2}$ & 1.673 & 0.415 & \pm 0.347 & & 0.034 & 0.022 & \pm 0.018 \\
$20-50 \mathrm{~km}^{2}$ & 0.886 & 0.266 & \pm 0.424 & & 0.017 & 0.010 & \pm 0.015 \\
大于 $50 \mathrm{~km}^{2}$ & 0.778 & 0.035 & \pm 0.056 & & 0.021 & 0.006 & \pm 0.009 \\
\hline
\end{tabular}

对所有监测流域按照耕地面积进行排序,选择耕地面积占 $35 \%$ 以上的共 19 个流域,所选流域子集内 耕地面积总体平均为 $53.38 \%$. 由于所选流域耕地面积不占绝对多数, 流域出口是流域内耕地和林地产出 的综合反映,不代表耕地的污染物产出. 然而如选择下游耕地分布集中的小流域进行监测, 又不能排除大的 居民点及部分工业点源的影响. 由于表 1 中已经获取了不同尺度小流域林地产出径流的面源污染浓度,利 用林地的统计结果结合径流计算可以估算出相应尺度的林地面源污染 TN、TP 产出,剔除 19 个流域中林地 的影响,计算相应尺度耕地产出径流的面源污染浓度,计算公式如下:

$$
\begin{aligned}
& E M C_{\text {耕地 }}=\left(Q_{\text {总 }} \times O M C-Q_{\text {林地 }} \times E M C_{\text {林地 }}\right) /\left(Q_{\text {总 }}-Q_{\text {林地 }}\right) \\
& Q_{\text {林地 }}=126.277 \times \mathrm{e}^{0.00128 P} \\
& Q_{\text {耕地 }}=64.0213 \times \mathrm{e}^{0.00149 P} \\
&
\end{aligned}
$$

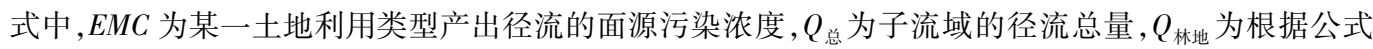

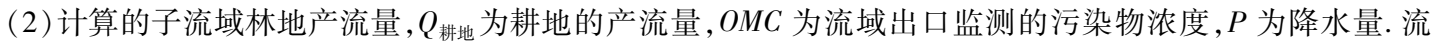


域径流计算公式 (2) 和 (3) 是基于该区 30 年长序列水文资料的统计分析结果, 在文献 22 中有详细介绍 ${ }^{[15]}$. 利用公式 (1) 及表 1 中相应尺度参数, 计算 19 个流域中耕地产出径流的 TN、TP 浓度, 将获取结果按照三个 典型尺度进行统计, 分析不同尺度小流域耕地产出径流 TN、TP 浓度统计特征, 如表 2 所示: $1-20 \mathrm{~km}^{2}$ 以上 流域耕地产出径流的 TN、TP 浓度分别为 $2.530 \pm 1.190 \mathrm{mg} / \mathrm{L}$ 和 $0.153 \pm 0.107 \mathrm{mg} / \mathrm{L} ; 20-50 \mathrm{~km}^{2}$ 尺度范围 内流域耕地产出径流的 TN、TP 浓度分别为 $2.338 \pm 0.742 \mathrm{mg} / \mathrm{L}$ 和 $0.165 \pm 0.125 \mathrm{mg} / \mathrm{L}$; 大于 $50 \mathrm{~km}^{2}$ 尺度流 域耕地产出径流的 TN、TP 浓度为 $2.518 \pm 0.829 \mathrm{mg} / \mathrm{L}$ 和 $0.197 \pm 0.160 \mathrm{mg} / \mathrm{L}$.

\section{表 2 不同尺度流域耕地产出径流的 TN、TP 浓度统计特征}

Tab. 2 The statistical feature of runoff concentration of TN \& TP from farm land

in different spatial scale watershed

\begin{tabular}{cccccccc}
\hline \multirow{2}{*}{ 流域面积 } & \multicolumn{3}{c}{$\mathrm{TN}(\mathrm{mg} / \mathrm{L})$} & & \multicolumn{3}{c}{$\mathrm{TP}(\mathrm{mg} / \mathrm{L})$} \\
\cline { 8 - 9 } \cline { 7 - 8 } & 均值 & 标准差 & $95 \%$ 置信范围 & 均值 & & 标准差 & $95 \%$ 置信范围 \\
\hline $1-20 \mathrm{~km}^{2}$ & 2.530 & 1.663 & \pm 1.190 & & 0.153 & 0.150 & \pm 0.107 \\
$20-50 \mathrm{~km}^{2}$ & 2.338 & 0.707 & \pm 0.742 & & 0.165 & 0.119 & \pm 0.125 \\
大于 $50 \mathrm{~km}^{2}$ & 2.518 & 0.521 & \pm 0.829 & & 0.197 & 0.146 & \pm 0.160 \\
\hline
\end{tabular}

\section{3 典型空间尺度流域面源污染浓度比较分析}

将本项研究获取的 4 个典型尺度面源污染浓度结果进行比较,如表 3 所示. 坡面流尺度面源污染浓度 是基于人工暴雨实验连续监测结果获得, 反映不同用地类型地表径流面源污染的初始产出特征. 3 个典型 小流域尺度为前面分析的结果,代表坡面汇流、沟谷汇流、河网汇流、土壤下渗滤减等生态系统营养盐调节 功能不同程度影响后的结果. 比较各尺度的参数发现, 坡面流尺度的面源污染浓度最高, 大于 3 个典型小流 域尺度的产出, 主要因为地表坡面流与小流域是局部与整体关系,坡面流在汇集过程中,经过坡面漫流、下 渗、坡面汇流、沟谷汇流等过程,这些过程都伴随着营养盐的滤过、土壤吸附等削减过程. 地表坡面流监测获 取的不同用地类型面源污染浓度差异与小流域也有所不同,坡面流实验样点林地面源污染浓度高于耕地, 与小流域的普遍结果有所不同, 导致这一结果有三个方面的原因, 其一是林地实验样点分布于坡度较大地 区,而耕地分布于平坦地区; 其二是与坡面流污染物浓度密切联系的表土成分具有较大的空间异质性,监测 结果空间差异较大; 其三是实测坡面流产出不包括壤中流,而小流域出口监测包括壤中流,代表流域最终的 产出, 两者之间虽然有一定的联系, 但不具有可比性, 是局部单一过程和整体过程的关系. 尤其在太湖流域, 壤中流是径流的重要形式之一,林木较粗的根系腐烂以后留下较多的管状空隙, 导致林地土层空隙度较大, 下渗及滤过能力强于耕地, 在壤中流形成和输移过程中, 林地生态系统对营养盐有较强的滤减作用. 综合以 上分析,坡面流监测空间尺度较小,受局地地表空间异质性影响较大,需要标准的空间采样方法才能获得代 表性参数,监测工作量大, 获得代表性结果较为困难. 而小流域空间尺度相对较大, 可以反映流域整体水文 过程,在面源污染估算中更具有代表性,产出浓度估算结果稳定性较好,可以通过典型流域监测获取区域代 表性估算结果.

表 3 典型空间尺度流域不同用地产出径流的 TN 、TP 浓度比较

Tab. 3 The comparison analysis of runoff TN \& TP concentration from different land use types among different typical spatial scale

\begin{tabular}{ccccc}
\hline \multirow{2}{*}{ 空间尺度 } & \multicolumn{2}{c}{ 林地产出径流浓度 $(\mathrm{mg} / \mathrm{L})$} & \multicolumn{2}{c}{ 耕地产出径流浓度 $(\mathrm{mg} / \mathrm{L})$} \\
\cline { 2 - 5 } & $\mathrm{TN}$ & $\mathrm{TP}$ & $\mathrm{TN}$ & $\mathrm{TP}$ \\
\hline 坡面流尺度 & $6.812 \pm 1.405$ & $2.125 \pm 0.693$ & $3.981 \pm 0.933$ & $0.807 \pm 0.188$ \\
$1-20 \mathrm{~km}^{2}$ 小流域 & $1.673 \pm 0.347$ & $0.034 \pm 0.018$ & $2.530 \pm 1.190$ & $0.153 \pm 0.107$ \\
$20-50 \mathrm{~km}^{2}$ 小流域 & $0.886 \pm 0.424$ & $0.017 \pm 0.015$ & $2.338 \pm 0.742$ & $0.165 \pm 0.125$ \\
大于 $50 \mathrm{~km}^{2}$ 小流域 & $0.778 \pm 0.056$ & $0.021 \pm 0.009$ & $2.518 \pm 0.829$ & $0.197 \pm 0.160$ \\
\hline
\end{tabular}


比较 3 个典型小流域尺度的产出特征, 发现接近自然的林地生态系统受尺度影响最为明显, 表现为 1 $-20 \mathrm{~km}^{2}$ 的流域尺度 TN、TP 产出浓度高于 $20-50 \mathrm{~km}^{2}$ 和 $50 \mathrm{~km}^{2}$ 以上的流域尺度的产出浓度, 而后两个流域 尺度的 TN、TP 产出浓度较为接近, 其中 $20-50 \mathrm{~km}^{2}$ 的流域林地 TN 产出浓度略高于 $50 \mathrm{~km}^{2}$ 以上的流域, 而 总磷略低. 由于 $1-20 \mathrm{~km}^{2}$ 流域主要反映壤中流侧渗汇人沟谷以及沟谷汇流过程, 由此可以得出: 接近自然 的林地生态系统因具有较强的下渗滤过机制和生态沟谷汇流网络, 对流域面源污染输出有较强的削减和调 节作用, 尤其是 $1-20 \mathrm{~km}^{2}$ 的流域尺度最为明显. 耕地生态系统产出浓度受尺度影响不显著, 三个尺度的 $\mathrm{TN} 、 \mathrm{TP}$ 较为接近, 而且趋势不明显, 受流域尺度增大, 人类活动增强的影响, 相对较为敏感的 TP 指标表现 出随尺度增加浓度略高的特征. 由耕地不同尺度面源污染产出浓度的比较结果得出, 耕地因较弱的下渗滤 过机制和人工沟渠汇流系统, 对营养盐的削减作用不明显, 由此可以得出现代农业造成流域面源污染产出 增加不仅仅是因为人类农业活动对流域局部土体及养分的改变, 而农业生态系统改变了自然生态系统整体 水文过程及营养盐调节机制是面源污染流失增加的重要因素之一. 因此恢复流域小尺度 $\left(1-20 \mathrm{~km}^{2}\right)$ 生态 沟谷汇流网络体系对面源污染削减有较为重要的作用. 由于受不同监测尺度影响, 获得小流域面源污染 TN、TP 产出浓度有较大差异, 在流域面源污染负荷估算中, 一定尺度的流域面源污染估算需要采用同一区 域相应尺度的产出浓度参数, 针对中尺度和更大尺度的流域, 可以采用次一级的流域浓度参数, 但需要同时 估算河网汇流过程伴随的营养盐削减和调节机制对流域地表径流氮磷污染物输出的影响.

\section{4 结论}

地表坡面流的面源污染 TN、TP 产出仅代表坡面冲刷，小流域的面源污染 TN、TP 产出是流域产汇流的 最终产出, 反映流域水文系统及生态系统整体影响的结果. 坡面流的面源污染浓度一般高于小流域的面源 污染浓度.

从径流浓度随暴雨历时的变化来看, 地表径流面源污染 TN、TP 浓度和暴雨径流过程所处的阶段有一 定的联系, 与流量、流速没有显著的联系. 坡面流浓度表现为降雨初期较高并逐渐下降趋于稳定, 而小流域 在整个暴雨径流过程中较为稳定, 浓度变化小于坡面流的变化.

比较径流面源污染浓度与流域尺度的关系揭示出, 接近自然的林地生态系统因较强的下渗滤过机制及 生态沟谷汇流网络, 对面源污染 TN、TP 有较强的削减和调节作用, $1-20 \mathrm{~km}^{2}$ 的流域尺度表现最为明显; 而 耕地生态系统因较弱的下渗能力以及人工沟渠汇流系统, 对面源污染 TN、TP 的削减和调节作用弱. 这一结 果证实恢复小尺度的生态沟谷网络系统对削减流域面源污染具有重要的意义.

流域不同空间尺度面源污染产出浓度估算结果的稳定性有较大差异, 一般表现为随空间尺度增大稳定 性增强的趋势, 在 $50 \mathrm{~km}^{2}$ 以上尺度估算结果稳定性好, 可以作为典型尺度获取代表性监测结果, 应用于流域 面源污染估算中. 本项研究获取太湖上游这一典型尺度估算结果为: 林地和耕地产出径流面源污染 TN 浓 度分别为 $0.778( \pm 0.056) \mathrm{mg} / \mathrm{L}$ 和 $2.518( \pm 0.829) \mathrm{mg} / \mathrm{L}, \mathrm{TP}$ 浓度分别为 $0.021( \pm 0.009) \mathrm{mg} / \mathrm{L}$ 和 0.197 $( \pm 0.160) \mathrm{mg} / \mathrm{L}$.

致谢野外监测样品分析由中科院湖泊沉积与环境开放实验室潘红筀完成, 中科院南京地理与湖泊研究所 “湖泊 - 流域基础数据库”为本项研究提供了部分地理数据,特此致谢.

\section{5 参考文献}

[1] Baird F C, Dybala T J, Jennings M E, et al. Characterization of non-point sources and loadings to the Corpus Christi Bay National Estuary Program Study Area. Corpus Christi National Estuary Program, Corpus Christi, TX. 1996.

[2] Budhendra B, Jon H, Bernie E, et al. Assessing watershed-scale, long-term hydrologic impacts of land-use change using a GIS-NPS model. Environmental Management, 2003, 26(6) : 643 - 658.

[3] Osborne K G. A water quality GIS tool for the city of Austin incorporating non-point sources and best management practices. The University of Texas at Austin, CRWR Report00 - 10, Austin Texas, 2000.

[4] Bernard Engel. Long-term hydrologic impacts assessment and non point source pollutant model. Version-2.3 
Manual, 2003, $1-7$.

[5] Chiew F H, Scanlon P J, Vertessy R A, et al. Catchment scale modeling of runoff, sediment and nutrient loads for South-East Queensland EMSS. Cooperative Research Centre for Catchment Hydrology, Report 02/ 1 , Canberra, 2002.

[6] 黄满向,章 申, 唐以剑等. 模拟降雨条件下农田径流中氮的流失过程. 土壤与环境, 2001, 10(1):6 -10 .

[7] 梁 涛, 张秀梅, 章 申等. 西苕溪流域不同土地类型下氮元素输移过程. 地理学报, 2002, 57 (4): $389-396$.

[8] 夏立忠,杨林章, 吴春加等. 太湖地区典型小城镇降水径流 N P 负荷空间分布的研究. 农业环境科学 学报, 2003,22(3):267-270.

[9] 连 纲, 王德建. 太湖地区麦季氮素淋失特征. 土壤通报, 2004, 35(2): 163-165.

[10] 王少平,俞立中, 许世远等. 苏州河非点源污染负荷研究. 环境科学研究, 2002, 15(6):20-27.

[11] 刘忠翰, 贺 涁, 王宜明等. 滇池不同流域类型降雨径流对河流氮磷人湖总量的影响. 地理研究, 2004, 23(9) : $593-604$.

[12] 王晓燕, 王晓峰, 汪清平等. 北京密云水库小流域非点源污染负荷估算. 地理科学, 2004, 24 (2): $227-231$.

[13] 黄云凤,张珞平,洪华生等. 不同土地利用对流域土壤侵蚀和氮、磷流失的影响. 农业环境科学学报, 2004, 23 (4) : $735-739$.

[14] 黄金良, 洪华生, 张珞平等. 基于 GIS 的九龙江流域农业非点源氮磷负荷估算研究. 农业环境科学学 报, 2004,23(5):866-871.

[15] 李恒鹏,刘晓玫,黄文钰. 太湖流域浙西区不同土地类型的面源污染产出. 地理学报,2004, 59(3): $401-408$. 